\title{
ThE ImPACT OF InSTITUTIONAL AND HUMAN RESOURCE Distance ON INTERNATIONAL ENTRY STRATEGIES
}

\author{
SAUL ESTRIN \\ Department of Management \\ London School of Economics \\ sestrin@1se.ac.uk \\ Delia Baghdasaryan * \\ French National Institute for Agricultural Research (INRA) \\ Grenoble Applied Economic Laboratory (GAEL) \\ Delia.Baghdasaryan@grenoble.inra.fr
}

\author{
KLAUS E. MeYer \\ School of Management \\ University of Bath \\ k.meyer@reading.ac.uk
}

forthcoming:

Journal of Management Studies, 2009

Key words: emerging economies, entry mode choice, foreign investment strategies, greenfield, institutional distance, institutional theory.

Author contact: Saul Estrin, Department of Management, London School of Economics, Houghton Street, London WC2A 2AE, United Kingdom, s.estrin@1se.ac.uk.

Acknowledgements: We thank three reviewers and editor Andrew Delios of the Journal of Management Studies, as well as conference participants at the Academy of International Business and the European International Business Academy for valuable comments. We thank the Social Science Foundation (Denmark) for financial support under grant number 2401-0152, and the Department for International Development (UK) for supporting this research under DFID/ESCOR project no. R7844, Centre for New and Emerging Markets, London Business School.

Note: * Earlier versions of this paper were circulated under the second author's maiden name, Delia Ionascu. 


\title{
The Impact of Institutional and Human Resource Distance on International Entry Strategies
}

\begin{abstract}
"Distance" between organisational contexts has been a prime concern of scholarly research into international business strategies. We extend this research by exploring the complementary roles of institutional and human resource distances on foreign investors' entry strategies. Combining institutional and resource-based theories suggests that (a) human resource differences complement institutional differences, (b) the effects of some aspects of distance are curvilinear, and (c) the impact of distance differs between first and subsequent entries. We find empirical support for these arguments on a unique dataset of foreign direct investment in six emerging economies that incorporates multiple host as well as multiple home countries.
\end{abstract}




\section{Introduction}

Multinational enterprises (MNEs) need to adjust to the multifaceted business environment of each host country (Peng, 2003; Dunning and Lundan, 2008a). This challenge increases with the differences between the foreign and MNE's home environment. The more "distant" is a host country from the organisational centre of the MNE, physically and in terms of mutual understanding, the more the firm has to bridge differences in culture, in laws and regulations, and in human resources (Shenkar, 2001; Tihanyi et al., 2005; Ghemawat, 2007). MNEs must adapt their business strategies and organisational forms to manage these differences (Kogut and Singh, 1988; Kostova and Roth, 2002).

National economies are shaped by the formal and informal rules that govern economic behaviour (North, 1990; Peng, 2003, Peng, Wang and Jiang, 2008) as well as their resource endowment, notably human resources (Narula and Dunning, 2000). In the same way, firms manage their resources with 'internal institutions', that is organisational structures and rules that govern the behaviour of actors within the firm. These internal institutions are often crucial for gaining and maintaining competitive advantages in the pertinent national context, and also have both formal and informal components (Dunning and Lundan, 2008a, b). Originally designed to attain competitive advantages in one context, internal institutions have to be adapted to achieve competitive advantages in another. These adaptations become more complex, the greater the difference between the national contexts (Kostova, 1999; Xu and Shenkar, 2002; Gaur and Lu, 2007).

The international business literature has developed the concept of "psychic distance" to address these issues; "the sum of factors preventing the flow of information from and to the market", which, among other aspects, encompasses "differences in language, education, business practices, culture and industrial development" (Johanson and Vahlne, 1977: 24). Research has focused on cultural aspects of distance though the findings are contradictory: a 
recent meta-analysis (Tihanyi, et al., 2005) shows that on average these studies do not generate a statistically significant effect, perhaps because of conceptual problems with psychic distance (Shenkar 2001; Harzing, 2003).

Our study contributes to the theoretical foundations of the research on distance in several ways. First, we build on recent calls to investigate broader concepts of distance $\mathrm{Xu}$ and Shenkar, 2002; Ghemawat, 2007) by distinguishing between formal and informal aspects of institutional distance (North 1990, Dunning and Lundan, 2008a, b), and by complementing them with differences in human resource endowments. We argue that both informal and formal differences should be taken into account in seeking to explain business strategies (Kostova and Zaheer, 1999; Xu and Shenkar, 2002). Second, we propose that the opposing forces of greater need and greater costs of working with local partners in culturally distant locations (Slangen and Hennart, 2008) combine to generate a curvilinear relationship between distance of informal institutions and strategic decisions. Third, we suggest that foreign investors who have already established themselves act differently from those who are making their first entry into a host context (Chang and Rosenzweig, 2001; Li and Meyer, 2009) because they already own some of the resources that first-time investors yet need to acquire. These contributions advance institutional theory within international business research (Peng, et al., 2008; Gelbuda, et al., 2008), and answer calls for complementing institutional with resource based theories (Wright et al., 2005; Meyer et al., 2009).

We test our propositions on a dataset covering multiple-host and multiple-home countries based on questionnaire surveys of foreign investors from 55 home countries who invest in six emerging economies in Europe, Asia and Africa. The high levels of variation of institutional and human resource contexts between source and recipient countries makes it unlikely that our results are driven by the idiosyncrasies of a particular source or host country.

In support of our theoretical arguments, we find that, the larger the distance in terms 
of formal institutions and resource endowment, the more likely that a first entry will take the form of a greenfield project. However, the impact of distance in informal institutions is found to be curvilinear. Subsequent entries by foreign investors show a similar pattern with respect to formal distance, but the opposite pattern with respect to resource distance. These findings provide theoretically grounded explanations for the apparent contradictions in previous studies in which a single measure of distance is employed.

\section{THEORETICAL PERSPECTIVES ON DISTANCE IN INTERNATIONAL BUSINESS}

MNEs choose investment sites in terms of 'locational advantages', which include their resource endowment and institutional environment (Dunning, 1998, 2009). Cross-national variations in resource endowments have been a pivotal element in early theories of the MNE (Vernon 1966; Dunning 1988), but have been rather neglected in more recent work. For example, countries that are rich in low-cost low-skilled labour provide opportunities for labour-intensive production and sales (Dawar and Chattopadhay, 2002; Meyer and Tran, 2006). Empirical work continues to highlight the relevance of relative resource endowments, notably of differences in labour costs (Bevan and Estrin, 2004).

National institutional frameworks - the formal and informal rules under which firms interact (North, 1990; 2005; Peng et al., 2008) - also influence business strategies, especially in emerging economies (Brouthers and Brouthers, 2001; Peng, 2003; Meyer et al., 2009). Firms create value by converting input resources into higher value output products. This process is governed by internal institutional arrangements that vary in their formal and informal aspects and often constitute part of their ownership advantages (Dunning and Lundan, 2008a). When entering foreign markets, MNEs need to adapt these internal institutions to the resources available (Tolbert, 1995) and to the institutions of the local environment (Kostova and Roth, 2002). Since internal processes and practices often make a 
major contribution to firms' competitive advantages, the ability to transfer them to other countries is essential to overcome their "liability of foreignness" (Zaheer 1995). Examples of successful transfers include employment practices (Oliver and Wilkinson, 1988), quality management processes (Kostova and Roth, 2002; Guler et al., 2002), human resource management practices (Gooderham et al., 1999) and environmental management processes (Christman and Taylor, 2001).

Affiliates also have to integrate with the MNE's global operations (Kostova and Roth, 2002). This dual integration becomes harder as the differences between the MNE's internal institutions and those in the host economy increase. For example, decentralisation and delegation of responsibilities are effective only if lower level managers have suitable qualifications to take decisions independently (Lowe, Morris and Wilkinson, 2000).

The choice of foreign entry mode is a key decision shaped by these conflicting demands (Tihanyi et al., 2005). Institutional variables have been shown to moderate entry modes (Meyer, 2001; Yiu and Makino, 2002; Gaur and Lu, 2007; Meyer et al., 2009), but not as yet with a theoretically grounded set of variables capturing the complexity of distance $(\mathrm{Xu}$ and Shenkar, 2002; Dunning and Lundan, 2008a). Alternative modes of entry provide foreign investors with different means to manage the dual challenges of distance: the benefits of access to resources held by local firms versus the costs of managing relationships with local partners and of transferring practices (Slangen and Hennart, 2008). Foreign entrants must therefore choose between entering alone and accessing context-specific resources embedded in local firms (Hennart and Park, 1993; Anand and Delios, 2002).

If the investing MNE's internal institutions are incompatible with those of local firms, it may choose a greenfield strategy. Such investors recruit and train staff to develop a workforce with qualifications and values that fit their organisational practices and create a local organisational structure that matches their global arrangements (Kogut and Singh, 1988; 
Hennart and Park, 1993). This reduces frictions between parent and subsidiaries and eliminates conflicts with local co-owners: greenfield investors do not have to compromise internal organisation in the ways necessitated by partial acquisitions or joint ventures.

However, even if legally feasible, greenfield projects do not provide access to resources of local firms, such as human resources (Kostova and Zaheer, 1999; Xu and Shenkar, 2002). "Cooperative modes" (joint venture, partial or full acquisition) make the human resources of the local partner available to the new operation, and provide access to local institutional and market knowledge that is often embedded in existing organisations (Anand and Delios, 2002; Meyer and Nguyen, 2005).

Investors' preferences between these entry modes will therefore vary with their need for local resources. A cooperative mode may be more appropriate for MNE's for which access to local resources is of greater significance than managing the relationship with a local partner. However, cooperation implies that the local organisation has to accommodate the institutional arrangements that exist within the partner firm, and this may inhibit the transfer of institutions from the foreign parent MNE. Various costs rise, including those for finding and evaluating potential partners, business negotiations, integration of local operations with the investors' global operation, and the transfer of organisational practices. Thus, distance raises both the benefits and the costs of cooperating with a local partner.

These issues are especially pertinent to first-time investors, as foreign investors who have previously been present in the country are likely to have learned how to operate in the local context and to make better use of the types of human resources available locally. Experience of operating within a particular context may offset the impact of distance. Once investors have built their own local resources and developed a better understanding of the contexts, access to local resources becomes less central as an objective for strategy design (Chang and Rosenzweig, 2001; Li and Meyer, 2009). Thus, foreign investors that already 
own a subsidiary in an emerging economy may be in a better position to establish a subsequent subsidiary than a first-time investor. Moreover, the distance between the new operation and the nearest existing affiliate, rather than headquarters, may be the relevant dimension for distance effects (Hutzschenreuter and Voll, 2008), especially when this nearest affiliate is in the same country. We initially focus our analysis on first time investors, and then also consider investors making subsequent entry decisions.

\section{HYPOTHESES}

The trade-offs between the need for partners and costs of partnering are influenced to varying degrees by different aspects of distance (Xu and Shenkar, 2002; Ghemawat, 2007). We focus on institutional distance, distinguishing between distance in formal and informal institutions, complemented with the concept of human resource distance.

\section{Distance in Formal Institutions}

Formal institutions set the rules by which economic actors have to interact (North, 1990), for instance when establishing contracts or employment relationships. When investors enter an unfamiliar legal context as first time entrants, they have to adapt their business practices such as their contracts with employees, agents, and distributors (Chang and Rosenzweig, 2001). Moreover, complex contracts, such as JVs, may be more difficult to design if the partners operate under different legal systems. Differences in formal institutions are likely to inhibit the transfer of business practices to acquired or co-owned local business units operating under local rules (Kostova and Roth, 2002). Local law, such as labour market regulations, may inhibit the exact replication of practices in existing organisations elsewhere. The required restructuring of the organisation would increase with institutional distance, yet the legal framework may constrain restructuring, especially if this involves staff redundancies. 
If local organizations are designed to fit very different formal institutions, then organizationally-embedded resources that local firms may offer are of less value to foreign investors because of higher costs of restructuring and adaptation. Therefore, first time entrants may eschew cooperative modes in favour of a greenfield investment that creates a new organisation in the MNE's own image (Kogut and Singh, 1988). Investors can train and socialise their workforce in the parent firm's organisational practices and establish processes that conform to the global organisation as well as local laws. In addition, they avoid problems related to design of contracts between partners that operate under different legal systems. Hence, we hypothesise that an increase in the distance between the formal institutions of the host and source economies would have a positive impact on MNEs' propensity to establish a greenfield project:

Hypothesis 1a: First-time investors are more likely to choose greenfield investment rather than a cooperative mode, the larger the distance in formal institutions between the home and the host countries..

\section{Distance in Informal Institutions}

Informal institutions are humanly devised constraints that are not formally codified but embedded in the shared norms, values and beliefs of a society (North, 1990; 2005). Even without codification, they may impose powerful restrictions on individual actors, and they are often very persistent even in the event of changes in formal institutions, say by an act of legislation. The notion of informal institutions encompasses culture as operationalised by Hostede (1980), Schwartz (1994) and others (Hofstede et al., 2002; Peng, 2003).

Knowledge about informal institutions is often tacit (Boyacigiller et al., 2004) so that engagements across culturally different environments require intensive cross-cultural communication. As a result, individual and organisational learning is typically rather slow. 
However, informal rules strongly influence economic behaviour because they moderate, for instance, the transfer and management of knowledge (Michailova and Hutchings, 2006). Consequently, the larger the difference in the informal institutions of the home and host countries, the greater is the need for local knowledge. Yet, the greater are also the difficulties of cooperating with those holding this knowledge (Kostova and Zaheer, 1999; Björkman et al., 2007). These opposing forces may explain contradictory results in earlier research (Slangen and Hennart, 2008).

Bridging cultural differences requires organisational learning, but this has been shown to relate non-linearly to outcomes and performance because incremental costs can eventually exceed incremental benefits (Kotabe et al., 2007). Meanwhile, when cultural differences become very large, "the two parties may be so different as to make it unlikely that they possess capabilities that are relevant for each other. Moreover, with growing cultural distance, the likelihood increases that the combining firms' practices are incompatible and lead to implementation problems. ... When taken together, these arguments suggest a curvilinear relationship between cultural differences and capability complementarity" (Björkman et al., 2007). We extend this line of argument by proposing that cultural distance for new entrants is curvilinearly related to entry mode choice.

When informal distance is low, cooperation between MNEs, even those entering for the first time, and local firms is relatively easy, with few barriers inhibiting communication. However, as distance increases, the costs of communication and collaboration increase because cultural differences are likely to inhibit the functioning of cooperative modes. New investors in distant locations may thus find it more challenging to integrate existing operations with a local firm or to manage a co-owner relationship with a local firm than to function on their own.

Beyond a certain threshold, however, greater informal distance causes the need for 
(tacit) local resources to increase so much that foreign investors without local experience are unable to function on their own. To ease external cross-cultural communication, they must cooperate with local firms that provide knowledge of the local business environment and help in managing cross-cultural interfaces. Institutional differences that are primarily of an informal nature may best be overcome gradually by experiential learning and thus by close interaction between individuals working directly together. Moreover, local partners may act as primary contact to local suppliers, distributors and authorities, thereby reducing the investor's direct interfaces with the unfamiliar environment. Greenfield investors have less local knowledge to draw upon when communicating with locals. They thus may find it harder to obtain access to tacit knowledge on local norms and business practices that are often embedded in local firms, especially when these norms and practices are fundamentally different from their own. Thus, investors may instead choose modes of entry that facilitate such learning. Hence, when distance of informal institutions becomes very high, interaction with the local environment will become more important, increasing the need to create links with local peers.

The opposing forces of the need to access local business networks and the costs of managing such relationships are likely to offset each other. This leads us to predict a nonlinear relationship between preference for new greenfield entry and cultural distance.

Hypothesis 1b: The likelihood of first-time investors choosing greenfield investment rather than a cooperative mode is curvilinearly (inverse $U$-shaped) relative to the distance in informal institutions between the home and the host countries.

\section{Human Resource Distance}

Firms adapt their practices and structures to the resources upon which they depend (Tolbert, 1995), including human resource systems (Schuler and Jackson, 1987, Lado and 
Wilson 1994). Different types of human resources require a variety of structures to achieve their full potential. For instance, highly skilled employees may prosper under a regime of high personal autonomy, while less skilled workforces may need more hierarchical structures, less delegation, and closer monitoring (Hofstede, 1993). Existing human resource management practices, transferred to another context, may thus not achieve the same results (Fey and Björkman, 2001; Fey et al. 2009).

In consequence, organisational structures and management practices will be adapted to the skill profiles that are available locally (Delmestri and Walgenbach, 2005; Baruch and Prawan, 2006). Local firms benefiting from an abundant workforce may use labour intensive production processes, whereas MNEs used to scarce labour have developed their practices around capital and technology intensive production (Kogut, 1985). Companies entering foreign countries for the first time may find the local workforce not able or willing to match their practices, and therefore must adapt their organisational structures to make better use of the available labour pool. For instance, Lowe, Morris and Wilkinson (2000) find skills of the local labour force were an important influence on the adaptation of management practices in Japanese-owned plants in Mexico and the UK.

Introducing suitable organisational structures and institutions for the existing workforce in the host country, while enabling the parent firm to preserve its extant competitive advantages, is easier if the new investors can select and train employees for the new operation. In a JV, the local partner would have a substantial say in recruitment decisions, especially in emerging economies where JVs are often created by transferring existing staff along with physical assets (Lyles and Salk, 1996; Estrin and Meyer, 2004).

The larger are these human resource differences, the larger the integration and coordination challenges of cooperative entry modes. A greater distance in human resources also increases the need to train the affiliate's employees, while reducing the likelihood that 
MNEs can impart the necessary skills. Moreover, the additional training expenditures increase the losses that MNEs incur in the eventuality of failure of the JV.

These adverse effects of human resource distance for new entrants may be reduced by selecting and training employees specifically for an operation using the foreign investor's business practices. Hence, in countries with very different human resources, investors may prefer to set up greenfield operations that allow them to select and train their staff in such a way that they fit in with the processes established in the global operation.

Hypothesis 1c: First-time investors are more likely to choose greenfield investment rather than a cooperative mode, the greater the distance between human resources in the home and host countries.

\section{Experienced Investors}

Prior local presence reduces both the benefits of having a local partner and the challenges of managing the relationship. Through a process of acculturation, MNEs develop familiarity with local environments in which they operate, which reduces the effects of distance (Johansen and Vahlne, 1977; Shenkar, 2001). Moreover, subsequent entries are often part of a strategy implemented in steps and build on the earlier operations (Meyer and Tran, 2006; Welsh, Benito and Pedersen, 2007).

In the case of formal institutions, many of the differences are codified and can be grasped relatively quickly by first-time foreign entrants; little is tacit or requires lengthy learning processes. Thus, local experience is unlikely to modify significantly how investors adapt to local formal institutions and we would expect the effect stipulated in Hypothesis 1a to apply equally to investors already established in the country:

Hypothesis 2a: The larger the distance of formal institutions between the home and host countries, the more likely are subsequent entries to take the form of greenfield 
investment than acquisition or joint venture.

In contrast, norms and beliefs are tacit and foreign entrants will typically only gradually build an understanding of how local informal institutions work, and how best to operate under those conditions (Björkman et al., 2007). However, having gone through this process of experiential learning when establishing a prior affiliate, MNEs that pursue subsequent entries can be expected to have built tacit knowledge of the local context.

Thus, the foreign investor has a better understanding of local culture during subsequent entries, which makes such differences less relevant for the design of strategies. Moreover, the investor can draw directly on resources of the existing operation to manage cultural conflicts. Hence, informal institutional distance matters less for experienced firms (compared to first-time investors), and would have little substantive effect on their strategies. We thus expect that it has no significant impact on entry mode choice by investors with previous investments in the country, and thus do not offer a testable hypothesis.

Foreign investors expanding from an existing local subsidiary have experience in managing different types of workforces (in both the local and their home context) and may have already developed human resource systems adapted to the workforce characteristics in the host country. If locally established foreign investors pursue ambitious growth projects such as the acquisition of a local firm, or establishment of a new operation with a local firm as co-owner, they can draw on their own locally knowledgeable managerial staff. Their competences in managing local workforces thus enable them to lead the workforce of an acquired business unit better than a newcomer.

Experienced investors are also in better position than inexperienced ones to spot suitable local partners with valuable human resources. Hence, with respect to human resource distance, investors undertaking subsequent entries may know better how to co-operate with local partners and acquire business units, and thus may be more likely to pursue cooperative 
entry strategies:

Hypothesis 2c: Subsequent entries are less likely in form of a greenfield investment rather than a cooperative mode, the greater the distance between human resources in the home and host countries.

$* * *$ Table 1 approximately here $* * *$

Table 1 summarises our hypotheses along with the results presented later. We distinguish between greenfield and cooperative modes, the latter encompassing partial and full acquisitions as well as JVs. We have argued that locally experienced investors choose their mode differently than those already present in the local context when facing informal institutional and resource distance, but not necessarily to differences in formal institutions. Our arguments are consistent with arguments by $\mathrm{Xu}$ and Shenkar (2002) and by Gaur and Lu (2007), who draw on the institutional theory developed in sociology and organisation theory (Kostova and Roth, 2002; Scott, 2005). They focus on mediating variables legitimacy, internal consistency, and practice adoption, which we consider to be special cases of, respectively, benefits and costs of cooperation.

\section{METHODOLOGY}

\section{Context and Data}

Our hypotheses require us to use a dataset about entry modes of FDI that varies across the dimensions of distance discussed above (Slangen and Hennart, 2007). Prior studies typically employ single-host multi-home, or multi-home single-host country datasets (see Tihanyi et al., 2005). Our multi-host, multi-source setting allows to overcome a major limitation of this literature, namely the inability fully to separate level and distance effects. 
The only studies of distance known to us that have substantive variation of home and host countries are Harzing (2002), who has nine source and 22 host countries, and Brouthers and Brouthers (2001) who have four home and five host countries. The latter dataset has been extended later for other types of research questions (Brouthers et al., 2008a, b).

We obtained data about foreign investment in six emerging economies, originating from 55 countries of origin. The host economies were selected using the criteria of significant FDI inflows and major liberalisation programmes during the previous decade, but they also varied significantly in their institutional context. This makes it unlikely that our results are driven by the idiosyncrasies of a particular source or host country or that we capture effects that hold only for a specific range of institutional or human resource distances. This latter point is particularly important given that for informal institutional distance we postulated a curvilinear effect.

The dataset is based on questionnaire surveys of foreign investors in Egypt, Hungary, India, Poland, South Africa and Vietnam created by merging two recent FDI surveys (Estrin and Meyer, 2004; Meyer and Estrin, 2007). In both, the base population, constructed from local databases, encompassed all registered FDI projects established within ten years before the survey, with a minimum employment of ten persons, and minimum foreign equity stake of $10 \%$. The first questionnaire was administered between November 2001 and April 2002 . Response rates ranged from $10 \%$ of the population in Egypt to $31 \%$ in South Africa. We replicated the methodology in a second study in Hungary and Poland in the year 2002, such that we obtained matching samples, with return rates of $11 \%$ and $10 \%$ respectively.

The dataset contains 876 observations. As is common in emerging markets, we lost some observations because respondents considered information to be too sensitive. We obtained 769 useable observations for regression analysis; a large sample for emerging economies research. We conducted T-tests on the main variables of interest (mode, 
experience, time of entry, R\&D intensity, etc) comparing firms with and without missing values to test for sample selection biases, and found no statistically significant differences. However, the tests suggest that relatively small parent firms are underrepresented in the final sample mainly because their response rates are slightly lower, and parent-specific data has often been incomplete for these firms. This seems unlikely to bias the estimates, albeit we shall be careful to make inferences about small parent firms.

\section{Empirical model}

We perform the econometric analysis using a Logit model in which the dependent variable is mode of entry, a dummy variable that takes a value of 1 if the foreign operation was set up as a greenfield investment and 0 otherwise. The testing of difference of effects between firsttime investor and experienced investors requires special care. We cannot employ moderating effects in Logit models as in OLS regressions because the magnitude of an interaction is not equal to the marginal effect of the interaction term. Rather, it can be of opposite sign and its statistical significance is not calculated by standard software (also see Ai and Norton, 2003, Shaver 2005). We instead split the sample in subsamples of first-time investors and experienced firms, and run the regression separately for both subsamples (as in Chang and Rosenzweig, 2001).

\section{Indices of distance}

Our hypotheses distinguish three aspects of distance - formal institutions, informal institutions and human resources. To measure them, we must use datasets that cover a wide range of countries, including Egypt and Vietnam. Formal institutional distance concerns laws and rules that influence business strategies and operations. To measure this concept comprehensively, we employ differences in the country measures of an index that covers a 
very broad range of formal institutions, the 'Regulatory Factor' of the Heritage Foundation Economic Freedom Index. This index includes six sub-indices: (a) Licensing requirements to operate a business, (b) ease of obtaining a business license, (c) corruption within the bureaucracy, (d) labour regulations, such as established workweeks, paid vacations, and parental leave, as well as selected labour regulations, (e) environmental, consumer safety, and worker health regulations, and (f) regulations that impose a burden on business (Beach and Miles, 2003). We use data for the year 2000, and compute the formal institutional distance as the absolute value of the difference between the measures of the home and host country (for detailed definitions and sources of the variables, see Table 2).

Informal institutional distance between countries concerns rules embedded in values, norms and beliefs (North, 1990; 2005). Values define what is preferred or desirable, while norms specify how things should be done and therefore delineate what a society perceives as accepted behaviour. Empirical studies usually employ the index developed by Kogut and Singh (1988) on the basis of Hofstede's (1980) work on national culture, for example to investigate how the distance between FDI's host and home countries influences entry mode choice (Tihanyi et al., 2005). An extensive literature suggests the relevance of distance as captured by Hofstede's indices for the entry mode decision (Barkema and Vermeulen, 1998; Chang and Rosenzweig, 2001 among many others) and recent evidence suggests consistency of results with those attained with other cultural distance measures (Kim and Gray, 2008).

However, there are widespread concerns regarding the validity of Hofstede's indices, because in 1980s, he could not use what would now be regarded as state-of-the-art statistical techniques when constructing and validating his indices (Shenkar, 2001; Javidan et al., 2006). Moreover, Hofstede's surveys were conducted in the 1970s, with some values, especially for emerging economies, being later estimates using different types of populations. Though Hofstede maintains that culture is substantially a constant over time (Hofstede, 2007), this is 
highly controversial, especially with respect to transition economies. Informal institutions, in contrast, are generally conceptualized as evolving over time (North 1990; 2005; Stoelhorst, 2008). However, if informal institutions evolve, then it would be imperative to supplement or substitute tests based on Hofstede's indices with more recent data. We thus complement tests based on these indices with similar indices advanced more recently by the GLOBE study (Javidan and House, 2001; House et al., 2006). This study developed nine indices based on recent surveys and using contemporary empirical techniques in their construction and validation (Javidan et al., 2006). Therefore we proxy informal institutional distance with two alternative indices, applying the formula proposed by Kogut-Singh to the Hofstede and GLOBE indices respectively. Methodologically, the GLOBE indices would be preferred, but GLOBE data are not available for as many countries as Hofstede data, so our tests using GLOBE indices are based on $21 \%$ fewer observations. In particular, the GLOBE study did not cover Vietnam, and in consequence, we lose one of our host countries altogether, which results in a considerable reduction in the variation of the various dimensions of distance.

We therefore conducted our analysis in two steps. First, we used the Hofstede-based indices as our measure of informal institutional distance, and then the GLOBE-based indices. From the GLOBE study, we select the 'practices' indices rather than the 'values' indices because foreign investors will be mainly concerned with the informal institutions that they actually encounter in the host country. Note both Hofstede's and the GLOBE study might capture marginal rather than the absolute levels of values (Maseland and Van Hoorn, 2008), which also suggests using the 'practices' indices.

We measure human resource distance by looking at source-host differences in two items of educational achievements and two items of exposure to new technologies. The education measures are the percentage of economically active population with tertiary education, and the average schooling years in the total population. We measure technology 
exposure by the number of computers and internet hosts per 1000 persons. We used the ILO Yearbook of Labor Statistics, OECD Statistics, and country Statistical Offices for the tertiary education measure. The average schooling measure comes from Barro and Lee (2000). For technology exposure, we used the World Development Indicators. Whenever possible, we used data for the year 2000; otherwise available data for the closest preceding year. Crombach's alpha analysis showed a 0.70 inter-item correlation.

\section{*** Table 2 approximateley here ***}

\section{Control variables}

Table 2 provides details of measurements and data sources for our control variables, including an experience dummy because we expect that experience in addition to the moderating effects, may also have a direct effect on mode choice.

Affiliate level controls: Foreign affiliates that are local market seeking need to set up local distribution networks, and are therefore less likely to establish greenfield investments, while affiliates whose main source of resources is its foreign parent, being less dependent on local inputs, are more likely. Affiliates that are horizontal investment in the same or a related industry as the parent, with industry-specific capabilities are more likely to be set up as a greenfield project (Hennart and Park, 1993). Similarly, affiliates of a small relative size compared to the parent may be easier to fund and resource internally and thus be established as a greenfield project.

Parent controls: Diversified foreign investors often rely on managerial control systems that accommodate diverse operations, are more likely to have been created through acquisitions and/or JVs and have a higher propensity to take this form. Other parent specific effects are controlled for by twenty industry dummies.

Host countries: Investment decisions are subject to a variety of host country-specific 
influences such as resource-endowment, levels of institutional development (Meyer, 2001; Peng, 2003) and political risk (Henisz and Delios, 2001), which may evolve over time. We control for them with country dummies and time trends.

Home countries: Using Ronen and Shenkar's (1985) methodology, we created dummies for home countries in 10 clusters - Anglo, Arab, Eastern Europe, Far East, Germanic, Japan and Korea, Latin Europe, Near East, Nordic, and Other. Furthermore, we include the Economic Freedom index for the home country to ensure that the distance measure does not pick up the level of economic freedom in the home country.

Table 3 presents the correlation matrix and descriptive statistics of the dependent and independent variables. The three dimensions of distance are correlated at between 0.260 and 0.376 , indicating that they refer to different concepts. Nonetheless to be cautious, we enter them singly before presenting a full model. Other correlations do not reach ranges for which multicollinearity would be a concern.

\section{*** Tables 3 and 4 approximately here $* * *$}

\section{RESULTS}

We report our results in Table 4 first for the full sample and then for subsamples of respectively first-time investors and experienced investors. Model 1 presents a base model for the full sample with all control variables, including home region and industry dummies, but without the effects of distance. The model yields overall high explanatory power, and the control variables have signs consistent with our expectations. These variables are highly relevant, explaining around $16 \%$ of the variation (as approximated by the pseudo $\mathrm{R}^{2}$ ). Thus, we conclude that the base model is fundamentally sound and largely consistent with prior empirical studies on entry modes. Among the control variables, market seeking, the source of main resources, and an expansion into a related business are highly significant. Prior 
experience in the host market has a negative effect on MNEs' propensity to establish greenfield subsidiaries, although this effect is not significant. This is probably due to the fact that, as we will see later, experience moderates the impact of various aspects of institutional distances on the entry mode choice differentially.

In models 2 to 5, we add the distance measures for the entire dataset. This changes little in the control variables, while the distance measures have similar results as the results for first-time investors (below), perhaps because we have substantially more first-time investors than experienced firms in the sample. Theoretical considerations suggest distinguishing first-time and experienced investors and we focus on the subsamples in discussing the results.

In models 6 to 9, we test hypotheses $1 \mathrm{a}, \mathrm{b}$ and $\mathrm{c}$ on the effects of distance for firsttime investors by adding the three dimensions of the institutional distance one at a time (Models 6 to 8), and then on the basis of a single model that includes the joint effect of distances (Model 9). The results show clear support for a positive effect of both formal institutional distance and resource distance on investors' preference for greenfield investment, as stipulated in hypotheses $1 \mathrm{a}$ and $1 \mathrm{c}$. Model 9 shows that these effects complement each other, i.e. different measures of distances capture different issues, and the joint model has the highest explanatory power.

As predicted in hypothesis $1 \mathrm{~b}$, the effect of informal institutional distance on greenfield entry is curvilinear (Model 2), and taking first derivatives of the non-linear function, we calculate the peak of the inverse U-shaped curve to be 2.74 , which about half a standard deviation above the mean. Thus, over most of the relevant range of this distance, the effect is positive, as for the other two measures of distance, but for high distance the direction of the effect is reversed.

In Models 10 to 13, we test hypotheses $2 \mathrm{a}$ and $\mathrm{c}$ about the impact of distances on 
investors already present in the host countries. In line with our predictions, the coefficients show a less uniform pattern than among first-time investors. Formal institutional distance has a positive effect on the probability of greenfield entry, as predicted in hypothesis $2 \mathrm{a}$, while human resource distance has a negative effect, as predicted in hypothesis $2 \mathrm{c}$.

\section{$* * *$ Table 5 approximately here ***}

In Table 5, we replicate the analysis for the smaller dataset for which GLOBE index data are available, and use the GLOBE-based distance measure to proxy informal distance. Overall, we see somewhat lower levels of significance, which is due to the smaller sample size and the reduced variation of distance in the sample.

For the focal variable, informal institutional distance, the results confirm the curvilinear shape for the full sample (Model 2a). However, the pattern for the subsamples is different in that using GLOBE indices experienced investors show a significant inverse-Ushaped pattern (Model 10a), while the pattern for first time investors in statistically not significant (Model 6a). When combining different measures of distance (Models 5a, 9a and 13a), some of the distance measures are no longer significant. We observed the same loss of significant in the combined model when using the Hofstede-based index on the reduced sample size, such that we can attribute this effect primarily to the loss of variation in the reduced dataset.

Hence, we can conclude that our data suggest that the relationship between informal institutional distance and the likelihood of greenfield entry is curvilinear in the aggregate sample, while there remains uncertainty regarding the relationships in specific sub-samples.

\section{DISCUSSION}

"Psychic distance" (Johansen and Vahlne, 1977) is a complex construct developed in the international business literature to analyze the effects of distance on international business 
strategies. Rich evidence suggests that it is highly relevant, yet empirical results are inconsistent so it remains unclear how and why it matters, for instance when firms set up a new operation abroad (Tihanyi et al., 2005). We have argued, and provided evidence, that this inconsistency may be cause by three effects:

First, multiple aspects of distance vary in their impact. The early literature focused on cultural distance, as measured by the Kogut and Singh (1988) index, and recent studies have complemented this with measures of formal institutional (or regulatory) distance (Xu and Shenkar, 2002; Xu et al., 2004; Gaur and Lu, 2007). We extend this argument by adding human resource distance, an aspect which has been overlooked so far but is relevant because companies arrange their organisational structures around the resources available to them. Different human resources thus require different human resource management practices. We find that the effect of human resource distance complements the effects of formal and informal institutional distance for first time investors, while causing opposite effects for investors already established in the country. More broadly this result suggests that distance has many dimensions, possibly including others not yet investigated in empirical studies (Ghemawat, 2007).

Second, effects of distance may be non-linear. The literature suggests that distance may simultaneously increase both costs and benefits of cooperative modes. We integrate these arguments and suggest that at low levels of distance, the cost effect may dominate, while at high levels, the benefits effect is more important. Our empirical support for this integrative argument provides a possible answer to concerns regarding the Hofstede-based Kogut-Singh measure of normative distance. A recent meta-analysis suggests that, across all contexts covered in previous research, cultural distance may not have a significant impact (Tihanyi, et al., 2005). In view of such contradictory evidence apparently driven by opposing effects, it may be surprising that non-linearity of the effects of distance have not been tested 
before. In part, differences to earlier studies are due to differences in the study design. First, we have a high variation of distance in our sample, which overcomes range limitation that may be present in earlier studies. Second, we use a multi-home multi-host country dataset and thus can be fairly confident that the distance measure does not substantially interact with level effects of the same variable as might be the case in single-host or single-home country dataset used in earlier research. ${ }^{*}$

Third, distance affects first-time and subsequent investments in different ways. Firms investing in a foreign context for the first time have little or no understanding of the local context, such that access to local resources, especially knowledge, rank highly among factors considered in designing the project. Yet once they have build or acquired such resources, this motive becomes less relevant (Chang and Rosenzweig, 2001; Delios and Henisz, 2003). Hence, distance becomes less of a concern, while in certain specific situations the investor combining distant origins with local expertise may be in a particularly strong position to undertake major operations, such as restructuring an acquired company. This may explain why we found experienced investors to pursue JVs or acquisitions when human resource distance is high. More broadly, this suggests experienced and inexperienced investors should be separated when analyzing distance and other effects on mode choice.

In developing our arguments, we have chosen to rely primarily on the Northian strand of institutional theory, which distinguishes formal and informal distance. We thus respond to the call of, for instance, Gelbuda et al. (2007) to develop institutional theory more rigorously without blending arguments that implicitly make different assumptions about the drivers of human behaviour. A key difference is the reference to the notion of legitimacy as motivator of activity in sociological theories, as opposed to assumption of rational behaviour and profit

\footnotetext{
* Future research may also take into consideration the possibility that investors take into consideration the possibility of a national psychic distance paradox, i.e. their own tendency to underestimate effects of informal institutional differences when distance is low (Brouthers et al., 2001). We thank reviewer 2 for pointing out this possibility. This argument would imply that strategic decisions over entry modes are made in anticipation of errors subsequently made by management at lower levels of the hierarchy.
} 
maximisation in economic theory. We have shown that institutional economics as developed by North and recently applied to multinational enterprises by Dunning and Lundan (2008 a, b) provides a solid foundation for theorizing about international business strategy.

However, the economic and sociological strands of institutional theory are complementary. Institutional sociology has looked at the effects of, for instance, mimetic behaviour and legitimacy (Kostova and Roth, 2002; Lu, 2002; Lu and Xu, 2006; Delios et al., 2008). Several studies in this tradition operationalise the concept of distance on the basis of Scott's (1995/2001) three 'pillars of the institutional framework' (Xu and Shenkar, 2002; Yiu and Makino, 2002; Gaur and Liu, 2007). The regulatory pillar corresponds to the formal institutions in North's (1990) and Dunning and Lundan's (2008) work, while Scott's normative and cognitive dimensions correspond to North's informal institutions (Peng, 2003; Meyer and Peng, 2005). A limitation of this approach may be that, having been developed at the level of individuals and organisations, it is not clear whether or how it should be translated when using nations as unit of analysis (Kostova and Roth, 2002). In particular, cognitive distance, one of the three pillars of Scott's (2005) model, would be hard to operationalise empirically at the national level (Xu et al., 2004). North focuses on national institutions, while acknowledging other levels, and thus lends itself more naturally to country level analysis. We choose not to blend these lines of theorizing because distinguishing between them allows for greater consistency and clarity (Gelbuda et al., 2008).

This discussion raises the issue of what is actually measured by the Kogut-Singh index. It has been used as a proxy for psychic distance (Kogut and Singh, 1988) and more recently for cultural distance (e.g. Brouthers and Brouthers, 2001; Chang and Rosenzweig, 2001; Harzing, 2002; Gaur et al., 2007). Psychic distance is a much broader and multidimensional construct that also encompasses not only culture but education, language and industrial development (Johanson and Wiedersheim-Paul, 1975; Johanson and Vahlne, 
1977; Luostarinen, 1980). Subsequent studies have focused on the more specific concept of culture, which itself is a broad concept that includes norms and values as well as shared assumptions and meanings (Shenkar 2001; Redding 2008). In consequence, there is considerable debate about whether and how best to measure cultural differences (Earley, 2006; Shenkar et al. 2008). Hofstede's (1980) conceptualization, which has become popular in the international management literature, conceived of culture in a narrower sense, focusing on norms and values, and presenting scales along which it can be measured.

The concepts of 'culture' and 'informal institutions' therefore originate in different literatures. The management literature has borrowed the concept of 'culture' from anthropology and sociology (Gregory 1983; Redding, 2008) and the concept of 'informal institutions' from economics (North 1990, 2005). We have chosen North's framework as our theoretical basis because it provides us with a clear and consistent terminology. North defines informal institutions as humanly devised constraints that are not formalized but embedded in norms, values and beliefs shared in a society (North 2005). This definition is close to some definitions of culture, in fact some authors such as Hofstede (1993, 2007) and Peng (2003) consider the two concepts as virtually identical. We take the view that Hofstede's indices capture norms and values and thus core aspects of both concepts. On the other hand, no measures are available for the more elusive aspects of either concept. Indices applying the Kogut-Singh formula probably provide the best available proxy for either concept.

\section{DIRECTIONS FOR FUTURE RESEARCH}

Taken together, our indicators of the institutional environment provide a richer measure of distance than the focus on cultural distance in the previous literature. Our approach may have particular relevance for studies of emerging markets, where the concept of institutional distance is particularly complex and multi-faceted, and a less coarse set of measures may 
greatly improve our understanding of business strategies. We have also sought to ensure that the indices that we propose are easily computable and are based on publicly accessible data; availability of suitable data is a major constraint on research about emerging markets. On this basis, we have established theoretically and empirically that aspects of distance may have different - even opposing - effects on business strategies.

Our approach has some limitations however. First, informal institutions are a broad concept that may be further disaggregated, for instance by exploring normative and cognitive aspects (Xu and Shenkar, 2002; Gaur and Lu, 2007), or using alternative empirical measures. We have conducted our tests using indices by Hofstede and GLOBE. Internal validity concerns would suggest using GLOBE because of its contemporary nature and methodological rigour, while external validity concerns suggest using Hofstede because of its broader coverage. We suggest that future research employs GLOBE where feasible, and this may imply focusing on samples that have a large coverage of countries covered by GLOBE. Scholars may also look at conceptualizations of 'culture' that encompass shared meanings, and thus are broader than the notion of informal institutions used in this study (Redding, 2008). Another promising avenue for research may be the direct measurement of perceptions of psychic distance, which would also account for asymmetries of psychic distance (Ambos and Håkanson, 2007).

Our measure of formal institutional distance corresponds closely to the theoretical construct. It is taken from a highly regarded source that in turn incorporates a very large survey; yet we do not have access to the individual components of this index and thus cannot conduct reliability tests of the index as are common for newly developed scales. Moreover, formal institutional distance might be subject to asymmetric effects in that adaptation from high economic freedom to low economic freedom would occur in different ways. While our dataset includes many source countries that have lower levels of economic freedom than the 
hosts, the majority comes from countries with higher levels. If there is such a moderating effect, it may not be fully controlled for in this study. Further research may explore this possibility by balancing developed and developing host countries in the sample.

This would also help to address a more general concern is the assumption of corporate and spatial homogeneity in the use of indices such as ours (Shenkar 2001; Mezias et al., 2002; Yiu and Makino, 2002). The use of indices reflecting the host or home economy, or the distance between them, assumes that the average of the respective country is an appropriate measure of the environment of the specific FDI project. However host economy institutions and resource endowments may vary internally (Meyer and Nguyen, 2005), while MNE's are exposed to different environments and develop their own unique corporate culture. Thus, indices of the national culture must always be approximations of the MNE organisation (Mezias et al., 2002) and the specific local business community into which it is entering.

Our dataset has many unique advantages, yet also has limitations. We have created a dataset with a large variation in our focal independent variable, institutional distance. Yet, it entails the limitations of a cross-sectional study. Institutions are widely believed to evolve over time (Hodgson, 2004; North 2005; Stoelhorst, 2008) and especially in emerging economies. Businesses - domestic and foreign - play an active role in a co-evolutionary process (Meyer and Nguyen, 2005; Tihanyi and Hegerty, 2007; Dielemann and Sachs, 2008). Future research may aim to measure host institutions and resources at the time prior to the entry, and thus exploit an additional source of variation.

\section{Conclusions}

Institutional differences between the home and host countries influence the strategies of foreign investors. Our empirical study of entry modes in six very diverse emerging economies shows that, in addition to aspects analyzed in earlier studies, human resource 
dimensions of distance between countries are highly relevant for international business strategies. In fact, different institutional aspects impact the entry mode decision in opposite ways and therefore, in order to capture the range of pressures that distance exerts on MNE's, researchers should consider all these aspects together. Thus, future research on distance in international business ought to incorporate the multi-dimensionality of distance, and the possibility of non-linear effects.

Moreover, we have shown that the effects of institutional distance are moderated by the investor's local experience. Distance reduces familiarity; yet experience can create familiarity. Hence some of the effects of distance on foreign investors diminish the longer the investor operates in the country. Future research on distance and business strategies should thus control for such moderating effects. The fact that scholars have ignored these moderations might explain the conflicting results obtained in previous research regarding the impact of country differences on the entry decision (Shenkar, 2001). 


\section{Table 1: Summary of Hypotheses and Results}

\begin{tabular}{|c|c|c|c|c|c|c|}
\hline & \multicolumn{3}{|c|}{ Hypotheses } & \multicolumn{3}{|c|}{ Results } \\
\hline & Formal & Informal & Human & Formal & Informal & Human \\
\hline & Institutions & Institutions & Resources & Institutions & Institutions & Resources \\
\hline $\begin{array}{l}\text { First-time } \\
\text { investor }\end{array}$ & + & $\cap$ & + & $+*$ & $\cap * *$ & $+* *$ \\
\hline $\begin{array}{l}\text { Experienced } \\
\text { investor }\end{array}$ & + & n.p. & - & $+* *$ & n.s. & $-* *$ \\
\hline Full sample & + & $\cap$ & n.p. & $+* *$ & $\bigcap * *$ & n.s. \\
\hline
\end{tabular}

Note: n.p. $=$ no prediction, n.s. $=$ not significant 
Table 2: Variables - Definitions and Sources

\begin{tabular}{|c|c|c|}
\hline Variable & Definition & Source \\
\hline $\begin{array}{l}\text { Formal institutional } \\
\text { distance }\end{array}$ & $\begin{array}{l}\text { Absolute distance on the level of regulations and } \\
\text { restrictions to operate a business }\end{array}$ & $\begin{array}{l}\text { Regulation Factor from the } \\
\text { Index of Economic } \\
\text { Freedom }(2000)\end{array}$ \\
\hline $\begin{array}{l}\text { Informal institutional } \\
\text { distance }(\mathrm{H})\end{array}$ & $\begin{array}{l}\text { Distance on four cultural dimensions defined by } \\
\text { Hofstede (1980). }\end{array}$ & Hofstede (2001) \\
\hline $\begin{array}{l}\text { Informal institutional } \\
\text { distance }(\mathrm{G})\end{array}$ & $\begin{array}{l}\text { Distance on nine cultural dimensions defined by the } \\
\text { GLOBE study. }\end{array}$ & House et al. (2004) \\
\hline Human resource & Distance on four dimensions: ${ }^{\mathrm{i}}$ & \\
\hline \multirow[t]{4}{*}{ distance } & $\begin{array}{l}\text { 1. Percentage of economically active population } \\
\text { that has attained at least tertiary education. Year: } \\
\text { 2000; Age: } 25+\end{array}$ & $\begin{array}{l}\text { ILO Yearbook of Labor } \\
\text { Statistics } 2001 \text { and } 2002 \text {, } \\
\text { OECD Statistics, country } \\
\text { Statistical Offices }\end{array}$ \\
\hline & $\begin{array}{l}\text { 2. Average schooling years in the total population. } \\
\text { Year: } 2000 \text {; Age: } 25+\end{array}$ & Barro and Lee (2000) \\
\hline & 3. Number of computers per 1000 persons & World Development \\
\hline & 4. Number of internet hosts per 1000 persons & $\begin{array}{l}\text { Indicators (WDI), } 2000 \\
\text { WDI (2000) }\end{array}$ \\
\hline Relative size & $\begin{array}{l}\text { The relative turnover of the affiliate and the parent } \\
\text { firm, assessed based on a Likert-type scale from one } \\
(0.0-0.1 \%) \text { to six (over } 20 \%) \text {. }\end{array}$ & FDI Survey \\
\hline $\begin{array}{l}\text { Experience } \\
\text { (commercial) }\end{array}$ & $\begin{array}{l}\text { Dummy: }=1 \text { if the investor had prior commercial } \\
\text { experience or have had prior affiliates in the host } \\
\text { country; = } 0 \text { otherwise }\end{array}$ & FDI Survey \\
\hline Experience (affiliate) & $\begin{array}{l}\text { Dummy: }=1 \text { if the investor had prior affiliates in } \\
\text { the host country; }=0 \text { otherwise }\end{array}$ & FDI Survey \\
\hline Market seeking & $\begin{array}{l}\text { Percentage of output sold in the domestic market } \\
\text { during the first year of business operation. }\end{array}$ & FDI Survey \\
\hline $\begin{array}{l}\text { Source of main } \\
\text { resource }\end{array}$ & $\begin{array}{l}\text { Percentage of the main resource that was obtained } \\
\text { from the foreign parent firm during the first two } \\
\text { years of operation (We asked respondents to select } \\
\text { the most important type of resources for their } \\
\text { affiliate's competitiveness. In a second question we } \\
\text { then asked to estimate what percentage of this } \\
\text { resource would be contributed by respectively the } \\
\text { foreign partner, the local partner, or other sources.) }\end{array}$ & FDI Survey \\
\hline Related industry & $\begin{array}{l}\text { Dummy }=1 \text { if one of affiliate's products is also } \\
\text { produced by its foreign parent; }=0 \text { otherwise. }\end{array}$ & FDI Survey \\
\hline Diversification & $\begin{array}{l}\text { Dummy }=1 \text { if the parent is a conglomerate } \\
\text { diversified into unrelated business sectors; }=0 \\
\text { otherwise. }\end{array}$ & FDI Survey \\
\hline $\begin{array}{l}\text { Time trends for each } \\
\text { country }\end{array}$ & $\begin{array}{l}\text { Year of legal establishment in a specific country - } \\
1989 \text { (= } 0 \text { if the host country is one of the other five } \\
\text { countries) }\end{array}$ & FDI Survey \\
\hline Country dummies & Five country dummies & FDI survey \\
\hline Industry dummies & $\begin{array}{l}\text { We have used } 4 \text { industry dummies: light industry, } \\
\text { heavy industry, IT, and utilities and services }\end{array}$ & FDI Survey \\
\hline
\end{tabular}

${ }^{\mathrm{i}}$ Distance is computed as $D=\sqrt{\sum_{i} \frac{\left(I_{i, h o s t}-I_{i, \text { origin }}\right)^{2}}{V_{i}}}$, where $I_{i, h o s t}\left(I_{i, \text { origin }}\right)$ is the $i$ th dimension of the

standardised index for the host country (country of origin). We used standardised values for each dimension since scales are not the same across dimensions. 
Table 3: Descriptive Statistics and Correlation Matrix

\begin{tabular}{|c|c|c|c|c|c|c|c|c|c|c|c|c|c|}
\hline & Variable & Mean & SD & Greenfield & 1 & 2 & 3 & 4 & 5 & 6 & 7 & 8 & 9 \\
\hline & Greenfield & 0.417 & 0.493 & 1 & & & & & & & & & \\
\hline 2 & Formal Institutional Distance & 0.962 & 1.018 & 0.132 & 0.165 & 1 & & & & & & & \\
\hline 3 & Human Resource Distance & 3.181 & 1.470 & 0.052 & 0.313 & 0.445 & 1 & & & & & & \\
\hline 4 & Market seeking & 71.59 & 40.44 & -0.103 & -0.003 & -0.157 & -0.088 & 1 & & & & & \\
\hline 5 & Source of main resource & 48.57 & 44.10 & 0.246 & 0.022 & 0.158 & 0.083 & -0.098 & 1 & & & & \\
\hline 6 & Relative size & 3.182 & 1.751 & 0.001 & -0.142 & -0.007 & -0.169 & -0.184 & -0.004 & 1 & & & \\
\hline 7 & Related industry & 0.914 & 0.281 & 0.085 & 0.025 & -0.121 & -0.150 & 0.047 & -0.004 & 0.034 & 1 & & \\
\hline 8 & Diversification & 0.114 & 0.318 & -0.066 & 0.033 & 0.213 & 0.057 & 0.013 & 0.037 & -0.121 & -0.147 & 1 & \\
\hline 9 & Experience & 0.254 & 0.435 & -0.079 & -0.022 & -0.039 & -0.022 & 0.024 & -0.110 & -0.070 & -0.017 & 0.094 & 1 \\
\hline 10 & Economic freedom & 7.013 & 0.722 & 0.068 & 0.134 & 0.377 & 0.655 & -0.051 & 0.036 & -0.019 & -0.062 & 0.045 & -0.005 \\
\hline
\end{tabular}

Note: correlations of larger than 0.1 are significant at $5 \%$ level.

Table 3a: Selected Correlations for the Reduced Sample

\begin{tabular}{lrrrrr}
\hline Variable & Greenfield & $\begin{array}{r}\text { Informal } \\
\text { dist. }(\mathrm{H})\end{array}$ & $\begin{array}{r}\text { Informal } \\
\text { dist. }(\mathrm{G})\end{array}$ & $\begin{array}{r}\text { Formal } \\
\text { distance }\end{array}$ & $\begin{array}{r}\text { Human } \\
\text { resource dist. }\end{array}$ \\
\hline Informal distance $(\mathrm{H})$ & 0.0198 & 1 & & & \\
Informal distance $(\mathrm{G})$ & 0.0706 & 0.3621 & 1 & & \\
Formal distance & 0.1283 & 0.1591 & -0.2681 & 1 & \\
Human resource distance & 0.0475 & 0.3082 & -0.2654 & 0.4415 & 1 \\
Market seeking & -0.1091 & -0.0045 & -0.0304 & -0.1597 & -0.094 \\
Source of main resource & 0.2417 & 0.0172 & 0.0206 & 0.1569 & 0.085 \\
Relative size & -0.0028 & -0.1439 & 0.0863 & -0.0108 & -0.1703 \\
Related industry & 0.0804 & 0.0291 & 0.1671 & -0.123 & -0.1507 \\
Diversification & -0.0655 & 0.0333 & -0.086 & 0.2131 & 0.057 \\
Experience & -0.0852 & -0.0215 & -0.0263 & -0.041 & -0.0212 \\
Economic freedom & 0.0642 & 0.1257 & -0.0994 & 0.3745 & 0.6545 \\
\hline
\end{tabular}


Table 4: Regression Results: Logit on Entry Mode Choice

\begin{tabular}{|c|c|c|c|c|c|c|c|c|c|c|c|c|c|}
\hline & \multicolumn{5}{|c|}{ Full Sample } & \multicolumn{4}{|c|}{ First-time investor sub-sample } & \multicolumn{4}{|c|}{ Experienced investor sub-sample } \\
\hline & (1) & (2) & (3) & (4) & (5) & (6) & (7) & (8) & (9) & (10) & (11) & (12) & (13) \\
\hline $\begin{array}{l}\text { Informal distance }(\mathrm{H}) \\
\quad \text { - squared }\end{array}$ & & $\begin{array}{c}1.169 * * \\
(2.33) \\
-0.213 * * \\
(2.20)\end{array}$ & & & $\begin{array}{c}1.012 * * \\
(2.00) \\
-0.208 * * \\
(2.14)\end{array}$ & $\begin{array}{c}1.055^{*} \\
(1.86) \\
-0.190^{*} \\
(1.69)\end{array}$ & & & $\begin{array}{c}1.024 * \\
(1.78) \\
-0.192 * \\
(1.71)\end{array}$ & $\begin{array}{l}0.855 \\
(0.60) \\
-0.110 \\
(0.43)\end{array}$ & & & $\begin{array}{l}0.316 \\
(0.21) \\
-0.062 \\
(0.22)\end{array}$ \\
\hline Formal distance & & & $\begin{array}{l}0.445^{* *} \\
(2.39)\end{array}$ & & $\begin{array}{l}0.472 * * \\
(2.34)\end{array}$ & & $\begin{array}{l}0.412^{*} \\
(1.88)\end{array}$ & & $\begin{array}{l}0.371 \\
(1.59)\end{array}$ & & $\begin{array}{l}0.859^{*} \\
(1.74)\end{array}$ & & $\begin{array}{l}0.990^{*} \\
(1.74)\end{array}$ \\
\hline Human resource distance & & & & $\begin{array}{l}0.080 \\
(0.70)\end{array}$ & $\begin{array}{l}0.070 \\
(0.59)\end{array}$ & & & $\begin{array}{l}0.342 * * \\
(2.41)\end{array}$ & $\begin{array}{c}0.347 * * \\
(2.35)\end{array}$ & & & $\begin{array}{c}-0.663 * * \\
(2.25)\end{array}$ & $\begin{array}{c}-0.720 * * \\
(2.33)\end{array}$ \\
\hline Market seeking & $\begin{array}{c}-0.006^{* *} \\
(2.51)\end{array}$ & $\begin{array}{c}-0.006^{* *} \\
(2.57)\end{array}$ & $\begin{array}{c}-0.006 * * * \\
(2.61)\end{array}$ & $\begin{array}{c}-0.006^{* *} \\
(2.49)\end{array}$ & $\begin{array}{c}-0.006^{* * *} \\
(2.60)\end{array}$ & $\begin{array}{c}-0.006^{* *} \\
(2.04)\end{array}$ & $\begin{array}{c}-0.006^{* *} \\
(2.04)\end{array}$ & $\begin{array}{c}-0.005^{*} \\
(1.73)\end{array}$ & $\begin{array}{c}-0.006^{*} \\
(1.92)\end{array}$ & $\begin{array}{l}-0.009 \\
(1.48)\end{array}$ & $\begin{array}{l}-0.009 \\
(1.46)\end{array}$ & $\begin{array}{l}-0.009 \\
(1.51)\end{array}$ & $\begin{array}{l}-0.009 \\
(1.34)\end{array}$ \\
\hline Source of main resource & $\begin{array}{c}0.010^{* * *} \\
(5.14)\end{array}$ & $\begin{array}{c}0.010 * * * \\
(5.03)\end{array}$ & $\begin{array}{c}0.010^{* * *} \\
(5.03)\end{array}$ & $\begin{array}{c}0.010^{* * *} \\
(4.99)\end{array}$ & $\begin{array}{c}0.009 * * * \\
(4.79)\end{array}$ & $\begin{array}{c}0.009 * * * \\
(4.16)\end{array}$ & $\begin{array}{c}0.010 * * * \\
(4.17)\end{array}$ & $\begin{array}{c}0.009 * * * \\
(4.02)\end{array}$ & $\begin{array}{c}0.009^{* * *} \\
(3.94)\end{array}$ & $\begin{array}{c}0.015 * * * \\
(2.85)\end{array}$ & $\begin{array}{c}0.014 * * * \\
(2.68)\end{array}$ & $\begin{array}{c}0.016^{* * *} \\
(3.13)\end{array}$ & $\begin{array}{c}0.015^{* * *} \\
(2.83)\end{array}$ \\
\hline Relative size & $\begin{array}{l}-0.041 \\
(0.78)\end{array}$ & $\begin{array}{c}-0.037 \\
(0.69)\end{array}$ & $\begin{array}{l}-0.036 \\
(0.68)\end{array}$ & $\begin{array}{l}-0.050 \\
(0.93)\end{array}$ & $\begin{array}{r}-0.042 \\
(0.79)\end{array}$ & $\begin{array}{l}0.010 \\
(0.16)\end{array}$ & $\begin{array}{l}0.016 \\
(0.26)\end{array}$ & $\begin{array}{l}0.022 \\
(0.35)\end{array}$ & $\begin{array}{l}0.028 \\
(0.44)\end{array}$ & $\begin{array}{c}-0.300^{* *} \\
(2.11)\end{array}$ & $\begin{array}{c}-0.322 * * \\
(2.27)\end{array}$ & $\begin{array}{c}-0.346^{* *} \\
(2.42)\end{array}$ & $\begin{array}{c}-0.340^{* *} \\
(2.31)\end{array}$ \\
\hline Related industry & $\begin{array}{l}0.568^{*} \\
(1.75)\end{array}$ & $\begin{array}{l}0.549^{*} \\
(1.68)\end{array}$ & $\begin{array}{l}0.596^{*} \\
(1.81)\end{array}$ & $\begin{array}{l}0.562^{*} \\
(1.71)\end{array}$ & $\begin{array}{l}0.574^{*} \\
(1.73)\end{array}$ & $\begin{array}{l}0.576 \\
(1.48)\end{array}$ & $\begin{array}{l}0.583 \\
(1.49)\end{array}$ & $\begin{array}{l}0.588 \\
(1.50)\end{array}$ & $\begin{array}{l}0.584 \\
(1.47)\end{array}$ & $\begin{array}{l}0.843 \\
(1.01)\end{array}$ & $\begin{array}{l}1.139 \\
(1.30)\end{array}$ & $\begin{array}{l}1.004 \\
(1.19)\end{array}$ & $\begin{array}{l}1.294 \\
(1.45)\end{array}$ \\
\hline Diversification & $\begin{array}{l}-0.455 \\
(1.62)\end{array}$ & $\begin{array}{l}-0.471^{*} \\
(1.67)\end{array}$ & $\begin{array}{l}-0.537^{*} \\
(1.88)\end{array}$ & $\begin{array}{l}-0.512^{*} \\
(1.79)\end{array}$ & $\begin{array}{c}-0.594 * * \\
(2.05)\end{array}$ & $\begin{array}{l}-0.266 \\
(0.75)\end{array}$ & $\begin{array}{l}-0.367 \\
(1.03)\end{array}$ & $\begin{array}{l}-0.322 \\
(0.89)\end{array}$ & $\begin{array}{l}-0.393 \\
(1.06)\end{array}$ & $\begin{array}{c}-1.612 * * \\
(2.45)\end{array}$ & $\begin{array}{c}-1.628^{* *} \\
(2.50)\end{array}$ & $\begin{array}{c}-1.800^{* * * *} \\
(2.65)\end{array}$ & $\begin{array}{c}-1.880 * * * \\
(2.75)\end{array}$ \\
\hline Experience & $\begin{array}{l}-0.144 \\
(0.73)\end{array}$ & $\begin{array}{l}-0.116 \\
(0.58)\end{array}$ & $\begin{array}{l}-0.136 \\
(0.69)\end{array}$ & $\begin{array}{l}-0.140 \\
(0.70)\end{array}$ & $\begin{array}{l}-0.110 \\
(0.54)\end{array}$ & & & & & & & & \\
\hline $\begin{array}{l}\text { Economic freedom } \\
\text { Constant }\end{array}$ & $\begin{array}{l}-0.302 \\
(1.62) \\
1.890 \\
(1.20)\end{array}$ & $\begin{array}{c}-0.201 \\
(1.03) \\
0.082 \\
(0.05)\end{array}$ & $\begin{array}{c}-0.372 * * \\
(1.97) \\
1.655 \\
(1.06)\end{array}$ & $\begin{array}{c}-0.363^{*} \\
(1.83) \\
1.204 \\
(0.70)\end{array}$ & $\begin{array}{c}-0.378^{*} \\
(1.81) \\
-0.316 \\
(0.17)\end{array}$ & $\begin{array}{l}-0.095 \\
(0.42) \\
-0.262 \\
(0.13)\end{array}$ & $\begin{array}{l}-0.228 \\
(1.05) \\
0.910 \\
(0.50)\end{array}$ & $\begin{array}{l}-0.394 * \\
(1.68) \\
1.047 \\
(0.54)\end{array}$ & $\begin{array}{l}-0.361 \\
(1.48) \\
-0.781 \\
(0.37)\end{array}$ & $\begin{array}{c}-1.781 * * \\
(2.52) \\
-8.620 \\
(1.19)\end{array}$ & $\begin{array}{c}-2.155^{* * *} \\
(2.89) \\
-6.338 \\
(0.93)\end{array}$ & $\begin{array}{c}-1.558^{* *} \\
(2.15) \\
-8.081 \\
(.)\end{array}$ & $\begin{array}{c}-1.842 * * \\
(2.33) \\
-7.791 \\
(1.09)\end{array}$ \\
\hline $\begin{array}{l}\text { No observations } \\
\chi^{2}(\mathrm{df})\end{array}$ & $\begin{array}{c}769 \\
162.27 \\
(47)\end{array}$ & $\begin{array}{c}769 \\
167.86 \\
(49)\end{array}$ & $\begin{array}{c}769 \\
168.02 \\
(48)\end{array}$ & $\begin{array}{c}768 \\
167.91 \\
(48)\end{array}$ & $\begin{array}{c}768 \\
178.63 \\
(51)\end{array}$ & $\begin{array}{c}575 \\
137.1 \\
(48)\end{array}$ & $\begin{array}{c}575 \\
137.04 \\
(47)\end{array}$ & $\begin{array}{c}574 \\
142.26 \\
(47)\end{array}$ & $\begin{array}{c}574 \\
148.97 \\
(50)\end{array}$ & $\begin{array}{c}183 \\
66.16 \\
(40)\end{array}$ & $\begin{array}{c}183 \\
68.74 \\
(39)\end{array}$ & $\begin{array}{c}183 \\
70.97 \\
(39)\end{array}$ & $\begin{array}{c}183 \\
74.85 \\
(42)\end{array}$ \\
\hline Pseudo $\mathrm{R}^{2}$ & 0.155 & 0.160 & 0.161 & 0.161 & 0.171 & 0.174 & 0.174 & 0.181 & 0.190 & 0.273 & 0.284 & 0.293 & 0.309 \\
\hline
\end{tabular}

Notes:

${ }^{*}=10 \%,{ }^{* *}=5 \%,{ }^{* * *}=1 \%$.

- All regressions include host country dummies and host country time trends, home cluster dummies, and industry dummies. 
Table 5: Regression Results: Alternative Measure for Informal Distance and smaller dataset

\begin{tabular}{|c|c|c|c|c|c|c|}
\hline & \multicolumn{2}{|c|}{ Full Sample } & \multicolumn{2}{|c|}{$\begin{array}{c}\text { First-time investor } \\
\text { sub-sample }\end{array}$} & \multicolumn{2}{|c|}{$\begin{array}{c}\text { Experienced investor } \\
\text { sub-sample }\end{array}$} \\
\hline & (1) & (2) & (5) & (6) & (9) & (10) \\
\hline Informal distance $(G)$ & $\begin{array}{l}1.274 * * \\
(2.35)\end{array}$ & & $\begin{array}{l}0.975 \\
(1.58)\end{array}$ & & $\begin{array}{l}3.478 * \\
(1.85)\end{array}$ & \\
\hline - squared & $\begin{array}{c}-0.104 * \\
(1.85)\end{array}$ & & $\begin{array}{l}-0.067 \\
(1.06)\end{array}$ & & $\begin{array}{l}-0.351 * \\
(1.84)\end{array}$ & \\
\hline Informal distance $(\mathrm{H})$ & & $\begin{array}{l}1.186^{*} \\
(1.93)\end{array}$ & & $\begin{array}{l}0.840 \\
(1.14)\end{array}$ & & $\begin{array}{l}1.466 \\
(0.85)\end{array}$ \\
\hline - squared & & $\begin{array}{c}-0.261 * * \\
(2.16)\end{array}$ & & $\begin{array}{l}-0.198 \\
(1.37)\end{array}$ & & $\begin{array}{l}-0.364 \\
(1.08)\end{array}$ \\
\hline Market seeking & $\begin{array}{c}-0.007 * * \\
(2.43)\end{array}$ & $\begin{array}{c}-0.007 * * \\
(2.42)\end{array}$ & $\begin{array}{l}-0.003 \\
(0.99)\end{array}$ & $\begin{array}{l}-0.003 \\
(1.07)\end{array}$ & $\begin{array}{c}-0.019 * * \\
(2.39)\end{array}$ & $\begin{array}{c}-0.017 * * \\
(2.18)\end{array}$ \\
\hline Source of main resource & $\begin{array}{c}0.010 * * * \\
(4.56)\end{array}$ & $\begin{array}{l}0.010 * * * \\
(4.63)\end{array}$ & $\begin{array}{c}0.009 * * * \\
(3.37)\end{array}$ & $\begin{array}{c}0.009^{* * *} \\
(3.47)\end{array}$ & $\begin{array}{l}0.018 * * * \\
(3.08)\end{array}$ & $\begin{array}{l}0.019 * * * \\
\quad(3.22)\end{array}$ \\
\hline Relative size & $\begin{array}{l}-0.058 \\
(0.97)\end{array}$ & $\begin{array}{l}-0.038 \\
(0.64)\end{array}$ & $\begin{array}{l}-0.032 \\
(0.46)\end{array}$ & $\begin{array}{l}-0.020 \\
(0.28)\end{array}$ & $\begin{array}{l}-0.236 \\
(1.41)\end{array}$ & $\begin{array}{l}-0.166 \\
(1.01)\end{array}$ \\
\hline Related industry & $\begin{array}{l}0.229 \\
(0.64)\end{array}$ & $\begin{array}{l}0.232 \\
(0.66)\end{array}$ & $\begin{array}{l}0.193 \\
(0.45)\end{array}$ & $\begin{array}{l}0.232 \\
(0.54)\end{array}$ & $\begin{array}{l}0.528 \\
(0.56)\end{array}$ & $\begin{array}{l}0.423 \\
(0.46)\end{array}$ \\
\hline Diversification & $\begin{array}{l}-0.468 \\
(1.38)\end{array}$ & $\begin{array}{l}-0.466 \\
(1.37)\end{array}$ & $\begin{array}{l}0.088 \\
(0.20)\end{array}$ & $\begin{array}{l}0.119 \\
(0.27)\end{array}$ & $\begin{array}{c}-1.703 * * \\
(2.08)\end{array}$ & $\begin{array}{c}-1.706^{* *} \\
(2.09)\end{array}$ \\
\hline Experience & $\begin{array}{l}-0.095 \\
(0.43)\end{array}$ & $\begin{array}{l}-0.048 \\
(0.22)\end{array}$ & & & & \\
\hline Economic freedom & $\begin{array}{l}-0.084 \\
(0.31)\end{array}$ & $\begin{array}{l}-0.097 \\
(0.36)\end{array}$ & $\begin{array}{l}-0.136 \\
(0.39)\end{array}$ & $\begin{array}{l}-0.121 \\
(0.36)\end{array}$ & $\begin{array}{l}-0.813 \\
(0.88)\end{array}$ & $\begin{array}{l}-0.915 \\
(1.00)\end{array}$ \\
\hline Constant & $\begin{array}{l}-2.713 \\
(1.12)\end{array}$ & $\begin{array}{r}-1.084 \\
(0.51)\end{array}$ & $\begin{array}{l}-2.911 \\
(0.99)\end{array}$ & $\begin{array}{l}-1.069 \\
(0.42)\end{array}$ & $\begin{array}{c}-16.432 \\
(1.52)\end{array}$ & $\begin{array}{c}-11.863 \\
(1.18)\end{array}$ \\
\hline $\begin{array}{l}\text { No observations } \\
\chi^{2}(\mathrm{df})\end{array}$ & $\begin{array}{c}610 \\
125.19 \\
(46)\end{array}$ & $\begin{array}{r}610 \\
122.45 \\
(46)\end{array}$ & $\begin{aligned} & 449 \\
96.59 & (44)\end{aligned}$ & $\begin{array}{l}\quad 449 \\
94.03 \\
(44)\end{array}$ & $\begin{array}{l}148 \\
65.69 \\
(35)\end{array}$ & $\begin{array}{l}\quad 148 \\
63.48 \\
(35)\end{array}$ \\
\hline Pseudo $\mathrm{R}^{2}$ & 0.152 & 0.149 & 0.159 & 0.155 & 0.333 & 0.322 \\
\hline
\end{tabular}

Notes:

- $\quad{ }^{*}=10 \%,{ }^{* *}=5 \%,{ }^{* * *}=1 \%$.

- All regressions include host country dummies and host country time trends, home cluster dummies, and industry dummies.

- The dataset is reduced compared to Table 4 due to the exclusion of countries for which GLOBE data are not available. 


\section{REFERENCES}

Ai, C. and Norton, E.C. (2003). Interaction terms in Logit and Probit models, Economic Letters 80, 123-129.

Ambos, B. and Håkanson, L. (2007). The Antecedents of Psychic Distance, proceedings (CD-R) of the European International Business Academy, Catania, Italy, December.

Anand, J. and Delios, A. (2002). Absolute and relative resources as determinants of international acquisitions, Strategic Management Journal, 23, 119-134.

Anderson, E. and Gatignon, H. (1986): Modes of foreign entry: A transaction cost analysis and propositions, Journal of International Business Studies 17, Fall, 1-26.

Barkema, H.G. and Vermeulen, F. (1998). International expansion through start-up or acquisition: A learning perspective, Academy of Management Journal, 41, 7-26.

Barro, R.J. and Lee, J.-W. (2000). International data on educational attainment: Updates and implications, NBER Working Paper No. 7911.

Baruch, Y. and Budhwar, P. S. (2006): A comparative study of career practices for management staff in Britain and India, International Business Review 15, 84-101.

Beach, W.W. and Miles, M.A. (2003). Explaining the economic freedom index, in: 2004 Index of Economic Freedom, The Heritage Foundation.

Bevan, A. and Estrin, S. (2004). The determinants of foreign direct investment into transition economies, Journal of Comparative Economics 32, 775-87.

Boyacigiller, N.A., Goodman, R.A. and Phillips, M.E. eds. (2004). Crossing Cultures: Insights from Master Teachers, New York: Routledge.

Brouthers, K.D. and Brouthers, L.E. (2001). Explaining the national cultural distance paradox, Journal of International Business Studies, 32, 177-189.

Brouthers, K.D. and Brouthers, L.E. (2003). Why service and manufacturing entry mode choices differ: The influence of transaction cost factors, risk and trust, Journal of Management Studies, 40, 1179-1204.

Brouthers, K.D., Brouthers, L.E. and Werner, S. (2008a): Resource-advantages in an international context, Journal of Management,34, 189-217.

Brouthers, K.D., Brouthers, L.E. and Werner, S. (2008b): Real options, international entry mode choice and performance, Journal of Management Studies, 45, 936-960.

Chang, S.-J. and Rosenzweig. P.M. (2001). The choice of entry mode in sequential foreign direct investment, Strategic Management Journal 22: 747-776.

Christman, P. and Taylor, G. (2001). Globalization and the environment: Determinants of firm self-regulation in China, Journal of International Business Studies 32, 439-458.

Chung, C.C. and Beamish, P.W. (2005). The impact of institutional reforms on characteristics of foreign subsidiaries in emerging economies, Journal of Management Studies, 42, 35-62.

Dawar, N. and A. Chattopadhay (2002): Rethinking marketing programs for emerging markets, 
Long Range Planning 35, 457-474.

Delios, A., Gaur, A.S. and Makino, S. (2008). The timing of international expansion: Information, rivalry and imitation among Japanese firms, 1980-2002, Journal of Management Studies, 45, 169-195

Delios, A. and Henisz, W.J. (2003). Political hazards, experience, and sequential entry strategies: The international expansion of Japanese firms, 1980-1998, Strategic Management Journal, 24, 1153-1164.

Delmestri, G. and Walgenbach, P. (2005). Mastering techniques or brokering knowledge? Middle managers in Germany, Great Britain and Italy, Organization Studies 26, 197-220.

Dielemann, M. and Sachs, W.M. (2008). Coevolution of institutions and corporations in emerging economies: How the Salim group morphed into an institution of Suharto's regime, Journal of Management Studies, 45(7), in press.

Dunning, J.H. (1988). Explaining International Production, London: Allen \& Unwin.

Dunning, J.H. (1998). Location and the multinational enterprise: A neglected factor, Journal of International Business Studies 29, 45-66.

Dunning, J.H. (2009). Location and the multinational enterprise: Retrospective thoughts, Journal of International Business Studies, 40(1), in press.

Dunning, J.H. and Lundan, S. (2008a). Multinational Enterprises and the Global Economy, $2^{\text {nd }}$ ed., Cheltenham: Elgar.

Dunning, J.H. and Lundan, S. (2008b). Institutions and the OLI paradigm of the multinational enterprise, Asia Pacific Journal of Management, 25, 573-593.

Earley, C.P. (2006) Leading cultural research in the future: a matter of paradigms and taste, Journal of International Business Studies 37, 922-931.

Estrin, S. and Meyer, K.E. (Eds.) (2004). Investment Strategies in Emerging Markets, Cheltenham: Edward Elgar.

Ferner, A., Almond, P. and Colling, T. (2005). Institutional theory and the cross-national transfer of employment policy: The case of 'workforce diversity' in US multinationals, Journal of International Business Studies 36, 304-321.

Fey, C. and \& Björkman, I. (2001). The effect of human resource management practices on MNC subsidiary performance in Russia, Journal of International Business Studies 32, 59-75.

Fey, Carl F., Morgulis-Yakushev, S., Park, H.J. and Björkman, I. (2009): Opening the black box of the relationship between HRM practices and firm performance: A comparison of MNC subsidiaries in the USA, Finland, and Russia, Journal of International Business Studies, forthcoming.

Gaur, A.S., Delios, A. and Singh, K. (2007). Institutional environments, staffing strategies, and subsidiary performance, Journal of Management 33, 611-636.

Gaur, A.S. and Lu, J. W. (2007). Ownership strategies and survival of foreign subsidiaries: 
Impacts of institutional distance and experience, Journal of Management 33, 84-110.

Gelbuda, M.; Meyer, K.E. and Delios, A. (2008). International business and institutional development in Central and Eastern Europe, Journal of International Management 14, 1-12.

Ghemawat, P. (2007): Redefining Global Strategy, Cambridge, MA: Harvard Business School Press.

Gooderham, P., Nordhaug, O. and Ringdal, K. (1999). Institutional and relational determinants of organizational practices: Human resource management in European firms, Administrative Science Quarterly 44, 507-531.

Gregory, K.L. (1983): Native view paradims: Multiple cultures and culture conflicts in organizations, Administrative Science Quarterly 28: 359-376.

Guler, I., Guillén, M.F. and MacPherson, J.M. (2002). Global competition, institutions, and the diffusion of organizational practices: The international spread of ISO9000 quality certificates, Administrative Science Quarterly 47, 207-232.

Harzing, A.W.K. (2002). Acquisitions versus greenfield investment: International strategy and management of entry modes, Strategic Management Journal 23, 211-227.

Harzing, A.W.K. (2003). The role of culture in entry mode studies: From neglect to myopia, Advances in International Management, 15, 75-127.

Henisz, W.J. and Delios, A. (2001). Uncertainty, imitation, and plant location: Japanese multinational corporations, 1990-1996. Administrative Science Quarterly, 46, 443-475.

Hennart, J.-F. and Y.-R. Park (1993). Greenfield vs. acquisition: The strategy of Japanese investors in the United States, Management Science, 39, 1054-1070.

Hodgson, G. M. (2004). The evolution of institutional economics: Agency, structure and Darwinism in American institutionalism, London: Routledge.

Hofstede, G. (1980). Culture's Consequences. New York: Sage.

Hofstede, Geert (1993): Cultural constraints in management theories, Academy of Management Executive 7, 81-94.

Hofstede, G. (2006) What did GLOBE really measure? Researchers' Minds versus respondents' minds, Journal of International Business Studies 37: 882-896.

Hofstede, G. (2007): Asian management in the $21^{\text {st }}$ century, Asia Pacific Journal of Management 24: 411-420.

Hofstede, G., Deusen, V.C., Mueller, C., Charles, T. and Business Goals Network (2002) 'What goals do business leaders pursue?' Journal of International Business Studies 33, 785-803.

Hoskisson, R.E., Eden, L., Lau, C.M. and Wright, M. (2000). Strategy in emerging economies, Academy of Management Journal, 43, 249-267.

House, R.J., Hanges, P.J., Javidan, M., Dorfman, P.W., and Gupta, V., Eds. (2004). Culture, leadership, and organisations: The GLOBE study of 62 societies. Thousand Oaks, CA: Sage Publications. 
Hutzschenreuter, T. and Voll, J.C. (2008). Performance effects of 'added cultural distance' in the path o international expansion: The case of German multinational enterprises, Journal of International Business Studies 39, 53-70.

Javidan, M. and House R.J. (2001): Cultural acumen for global managers: Lessons from project GLOBE, Organizational Dynamics 29(4): 289-305.

Javidan, M.; House, R.J.; Dorfman, P.W.; Hanges, P.J. and Du Luque, S. (2006): Conceptualizing and measuring cultures and their consequences: A comparative review of GLOBE's and Hofstede's approaches, Journal of International Business Studies 37: 897-914.

Johanson, J. and Vahlne, J.-E. (1977). The internationalization process of the firm - a model of knowledge development and foreign market commitment, Journal of International Business Studies, 8, 23-32.

Johanson, J. and Wiedersheim-Paul, F. (1975). The internationalozation of the firm: Four Swedish cases, Journal of Management Studies 12: 305-322.

Khanna, T. and Palepu, K. (2000). The future of business groups in emerging markets: long-run evidence from Chile, Academy of Management Journal, 43, 268-285.

Kim, Y. and Gray, S. (2008). An assessment of alternative empirical measures of cultural distance in explaining foreign ownership mode decisions: Evidence from the Republic of Korea, Asia Pacific Journal of Management, in press.

Kogut, B. (1985): Designing global strategies: Comparative and competitive value added chains, Sloan Management Review 26, 15-28.

Kogut, B. and Singh, H. (1988). The effect of national culture on the choice of entry mode, Journal of International Business Studies, 19, 411-432.

Kostova, T. (1999): Transnational transfer of strategic organizational practices: A contextual perspective, Academy of Management Review, 24, 308-324.

Kostova, T. and Roth, K. (2002). Adoption of an organizational practice by subsidiaries of multinational corporations: Institutional and relational effects, Academy of Management Journal, 45, 215-233.

Kostova, T. and Zaheer, S. (1999). Organizational legitimacy under conditions of complexity: The case of the multinational enterprise, Academy of Management Review, 24, 64-81.

Lado, A. and Wilson, M. (1994) 'Human resource systems and sustained competitive advantage: a competency based perspective', Academy of Management Review 19, pp.699-727.

Li, P.-Y. and Meyer, K.E. (2009): Contextualizing experience effects in international business: A study of ownership strategies, Journal of World Business 44(4), forthcoming

Lowe, James; Morris, Jonathan and Wilkinson, Barry (2000): British factory, Japanese factory and Mexican factory: An international comparison of front-line management and supervision, Journal of Management Studies 37: 541-560.

Lu, J.W. (2002). Intra- and inter-organizational imitative behavior: Institutional influences on 
Japanese firms' entry mode choice", Journal of International Business Studies, 33, 19-38.

Lu, J.W. and Xu, D. (2006). Growth and survival of international joint ventures: External-internal legitimacy perspective, Journal of Management, 32, 426-448.

Luostarinen, R. (1980). Internationalization of the firm, Helsinki: Helsinki School of Economics.

Lyles, M.A. and Salk, J. 1996. Knowledge acquisition from foreign parents in international joint ventures: An empirical examination in the Hungarian context', Journal of International Business Studies 27: 877-903.

Maseland, R. and Van Hoorn, A. (2008). Explaining the negative correlation between values and practices: A note on the Hofstede-GLOBE debate, Journal of International Business Studies, in press (doi: 10.1057/jibs.2008.68)

Meyer, K.E. (2001). Institutions, transaction costs and entry mode choice in Eastern Europe, Journal of International Business Studies, 32, 357-367.

Meyer, K.E. and Estrin, S. (Eds) (2007). Acquisition Strategies in European Emerging Economies, Basingstoke: Palgrave-Macmillan.

Meyer K.E., Estrin, S., Bhaumik, S.K, and Peng M.W. (2009). Institutions, resources and entry strategies in emerging economies. Strategic Management Journal, 30, 61-80.

Meyer, K.E. and Nguyen, H.V. (2005). Foreign investment strategies and sub-national institutions in emerging markets: Evidence from Vietnam, Journal of Management Studies, 42, 63-93.

Meyer, K.E. and Peng, M.W. (2005). Probing theoretically into Central and Eastern Europe: Transactions, resources and institutions, Journal of International Business Studies, 36, 600621.

Meyer, K.E. and Tran, Y.T.T. (2006). Market penetration and acquisition strategies for emerging economies, Long Range Planning, 39, 177-197.

Mezias, S.J. (2002). National cultural distance as liability of foreignness: the issue of level of analysis, Journal of International Management, 8, 407-421.

Michailova, S. and Hutchings, K. (2006). National cultural influences on knowledge sharing: A comparison of China and Russia, Journal of Management Studies, 43, 383-406.

Narula, R. and Dunning, J.H. (2000). Industrial development, globalization and multinational enterprises: New realities for developing countries, Oxford Development Studies, 38, 141167.

North, D. (1990). Institutions, institutional change, and economic performance, New York: Norton.

North, D. (2005). Understanding the Process of Economic Change, Princeton, NJ: Princeton University Press.

Oliver, N. and Wilkinson, B. (1988). The Japanization of British Industry, Oxford: Basil Blackwell. 
Peng, M.W. (2003). Institutional transitions and strategic choices, Academy of Management Review, 28, 275-296.

Peng, M.W., Wang, D.Y.L. and Jiang, Y. (2008). An institution based view of international business strategy: A focus on emerging economies, Journal of International Business Studies, 39, 920-936.

Redding, G. (2008): Separating Culture from Institutions: The Use of Semantic Spaces as a Conceptual Domain and the Case of China, Management Organization Review 4, 257-289.

Ronen S. and Shenkar O. (1985). Clustering countries on attitudinal dimensions: a review and synthesis, Academy of Management Review 10: 435-454.

Schuler, R.S. and Jackson, S.E. (1987). Linking competitive strategies with human resource management practices, Academy of Management Executive, 1, 207-219.

Schwartz, S.H. (1994). Beyond individualism-collectivism: New cultural dimensions of values. In E. Kim, H.C. Triandis, C. Kagitcibasi, S-C. Choi, \& G. Yoon (eds.), Individualism and Collectivism: Theory, Method and Applications: 85-119. Newbury Park, CA: Sage.

Scott, W.R. (2001). Institutions and Organizations, $2^{\text {nd }}$ edition ( $1^{\text {st }}$ edition: 1995), Thousand Oaks, CA: Sage.

Shaver, J.M. (2005). Testing for mediating variables in management research concerns, implications and alternative strategies, Journal of Management, 31, 330-353.

Shenkar, O. (2001). Cultural distance revisited: Towards a more rigorous conceptualization and measurement of cultural differences, Journal of International Business Studies, 32, 519-535.

Shenkar, O., Luo, Y. and Yeheskel, O. (2008). From 'Distance' to 'Friction': Substituting metaphors and redirecting cross-cultural research, Academy of Management Review 33: 905-923.

Slangen, A.H.L. and Hennart, J.-F. (2007). Greenfield or acquisition: A review of the empirical foreign establishment mode literature, Journal of International Management, 13, 403-429.

Slangen, A.H.L. and Hennart, J.-F. (2008). Do multinational really prefer to enter culturally distant countries through greenfields rather than through acquisitions? The role of parent experience and subsidiary autonomy, Journal of International Business Studies, 39, 472-490.

Stoelhorst, J.W. (2008). Why is management not an evolutionary science? Evolution theory in strategy and organization, Journal of Management Studies, 45, 1008-1023.

Tihanyi, L., Griffith, D.A. and Russel, C.J. (2005). The effect of cultural distance on entry mode choice, international diversification, and MNE performance: A Meta-analysis, Journal of International Business Studies, 36, 270-283.

Tihanyi, L. and Hegerty, L. (2007). Political interests and the emergence of commercial banking in transition economies, Journal of Management Studies, 44, 788-813.

Tolbert, P.S. (1985). Institutional environments and resource dependence: Sources of administrative structure in higher education, Administrative Science Quarterly 30, 1-13. 
$\mathrm{Xu}, \mathrm{D}$. and Shenkar, O. (2002). Institutional distance and the multinational enterprise, Academy of Management Review, 27, 608-618.

$\mathrm{Xu}, \mathrm{D}$., Y. Pan, and Beamish, P.W. (2004), The effect of regulative and normative distances on MNE ownership and expatriate strategies, Management International Review, 44, 285-307.

Yiu, D. and Makino, S. (2002). The choice between joint venture and wholly owned subsidiary: An institutional perspective, Organization Science 13, 667-683.

Vernon, R. (1966). International investment and international trade in the product cycle, Quarterly Journal of Economics, 80, 190-207.

Welsh, L., Benito, G. and Pedersen, B. (2007): Foreign Operation Methods: Analysis, Strategy, and Dynamics. London: Edward Elgar

World Bank (2000). World Development Indicators, Year 2000. Washington, DC: World Bank.

Wright, M., Filatotchev, I., Hoskisson, R. and Peng, M.W. (2005). Strategy research in emerging economies: Challenging the conventional wisdom, Journal of Management Studies, 42, 121.

Zaheer, S. (1995). Overcoming the liability of foreignness, Academy of Management Journal, 38, 341-363. 